\title{
Sporacetigenium mesophilum gen. nov., sp. nov., isolated from an anaerobic digester treating municipal solid waste and sewage
}

\author{
Shuangya Chen, ${ }^{1,2}$ Lei Song $^{1,2}$ and Xiuzhu Dong ${ }^{1}$
}

Correspondence

Xiuzhu Dong

dongxz@sun.im.ac.cn
Hydrogen is a clean energy source which has potential applications for the future. Although hydrogen is traditionally produced by hydrocarbon reformation or electrolysis of water, it might also be produced by micro-organisms (Nandi \& Sengupta, 1998) via either fermentation or photosynthesis. Among the fermentative bio-hydrogen-producing bacteria, the clostridia are the most common group. Basically, there are two types of hydrogen-producing metabolism represented in the clostridia: most of them perform butyrate fermentation, by-producing large amounts of butyrate and acetate as concomitant main products during hydrogen-producing fermentation, while only a few produce ethanol and acetate as concomitant products (Cato et al., 1986). According to phylogenetic analysis based on 16S rRNA gene sequences, 19 clusters were proposed within the genus Clostridium (Collins et al., 1994). Collins et al. (1994) also demonstrated that Clostridium was not a monophyletic group and that

Published online ahead of print on 2 December 2005 as DOI 10.1099/ ijs.0.63686-0.

Abbreviation: DAP, diaminopimelic acid.

The GenBank/EMBL/DDBJ accession number for the 16S rRNA gene sequence of Sporacetigenium mesophilum ZLJ $115^{\top}$ is AY682207.

Fatty acid profiles of the novel strains are available as supplementary material in IJSEM Online. many species needed to be reclassified. Members of cluster XI exhibit a wide range of physiological and metabolic characteristics, and the cluster includes alkaliphiles (Li et al., 1993, 1994), halophiles (Fendrich et al., 1990) and thermophiles (Alain et al., 2002).

During the survey and isolation of hydrogen-producing bacteria from a variety of polysaccharides and proteinaceous compounds, we isolated two obligately anaerobic, sporeforming bacterial strains from the sludge of an anaerobic digester treating municipal solid waste and sewage in Zhangzhou city, Fujian province, PR China. The strains produced $\mathrm{H}_{2}$, acetic acid and ethanol from glucose fermentation. Phylogenetically, the strains were affiliated to cluster XI of the clostridia; however, they were distantly related to any described members in this cluster. Based on their distinctive phenotypic, genomic and phylogenetic characteristics, a novel genus and species are proposed.

Strains ZLJ115 ${ }^{\mathrm{T}}$ and L4-2 were isolated in pre-reduced peptone/yeast extract/glucose (PYG) medium (Holdeman et al., 1977) by serial dilution and the roll-tube technique (Hungate, 1969). Single colonies were picked and transferred to the same broth and incubated at $37^{\circ} \mathrm{C}$ for 2 days. The rolling tube procedure was repeated several times until a pure culture was obtained. Culture purity was also checked 
by microscope examination. Routine cultivation was in PYG broth in anaerobic tubes $(18 \times 180 \mathrm{~mm})$ sealed with butylrubber stoppers under a gaseous atmosphere of $100 \% \mathrm{~N}_{2}$ $(100 \mathrm{kPa})$ at $37^{\circ} \mathrm{C}$.

Cell morphology was examined under a light microscope (Olympus BH-2) as well as an electron microscope (Hitachi $\mathrm{H}-600 \mathrm{~A}$ ) after negative staining with uranyl acetate. Generation time of the strains was determined by monitoring the $\mathrm{OD}_{600}$ of a PYG broth culture at $37^{\circ} \mathrm{C}$ at $1 \mathrm{~h}$ intervals up to $48 \mathrm{~h}$. Temperature profiles were determined in PYG broth using a water bath (Guangming medical instrument plant, Beijing) at temperatures of $15-55^{\circ} \mathrm{C}$ at $1{ }^{\circ} \mathrm{C}$ intervals. The $\mathrm{pH}$ range for growth was determined for the culture in PYG broth at various $\mathrm{pH}$ values adjusted with $\mathrm{HCl}$ or $\mathrm{NaOH}$ $(1 \mathrm{M})$. Growth was determined by measuring the $\mathrm{OD}_{600}$ of the cultures at 1, 3 and 7 days. Biochemical traits were determined using both conventional methods and the API $50 \mathrm{CH}$ system (bioMérieux). All tests were performed in duplicate.

Genomic DNA was extracted and purified using the method of Marmur (1961). The G+C content of the DNA was determined by the thermal denaturation method (Marmur \& Doty, 1962) using a Beckman DU800 spectrophotometer with Escherichia coli K-12 as the reference. The 16S rRNA gene was amplified by PCR and sequenced as described previously (Chen \& Dong, 2004). DNA-DNA relatedness was determined on the basis of the DNA-DNA liquid reassociation rate (De Ley et al., 1970) at $65^{\circ} \mathrm{C}$ using a Beckman DU 800 spectrophotometer.

The 16S rRNA gene sequence of strain $\mathrm{ZLJ} 115^{\mathrm{T}}$ was submitted to GenBank and EMBL to search for similar sequences using the BLAST algorithm. The best matching sequences were retrieved from the database and aligned and similarity analysis was performed using the program CLUSTAL_X (Thompson et al., 1997). Phylogenetic trees were constructed using the neighbour-joining, maximumlikelihood and maximum-parsimony methods implemented in the program MEGA2 (Kumar et al., 2001) and the PHYLIP package (Felsenstein, 1993). The resultant tree topologies were evaluated by bootstrap analysis (Felsenstein, 1985) based on 1000 resamplings.

Short-chain fatty acids and gases produced from fermentation in PYG medium were measured using a gas chromatograph (GC-14B; Shimadzu) according to Chen \& Dong (2004). Diagnostic isomers of diaminopimelic acid (DAP) in the cell wall were determined with established TLC procedures (Lechevalier \& Lechevalier, 1980). Cellular fatty acids were extracted, methylated and analysed using the standard MIDI (Microbial Identification) system (Miller, 1982; Sasser, 1990).

Cells of strains ZLJ115 ${ }^{\mathrm{T}}$ and L4-2 were Gram-positive rods $(0 \cdot 9-1 \cdot 0 \times 3 \cdot 6-7 \cdot 3 \mu \mathrm{m})$, occurring singly or in short chains and motile by peritrichous flagella. The Gram-positive cell wall structure was also confirmed by the $\mathrm{KOH}$ lysis test
(Smibert \& Krieg, 1994). In the late stationary phase of growth, ovoid endospores were formed in the ends of cells, resulting in swollen cells. Colonies on PYG agar were milkwhite, smooth, circular, entire and translucent, slightly convex and reached $1 \mathrm{~mm}$ in diameter after cultivation at $37^{\circ} \mathrm{C}$ for $48 \mathrm{~h}$.

Strains ZLJ115 ${ }^{\mathrm{T}}$ and L4-2 grew exclusively in pre-reduced media and growth was inhibited completely by air. Both strains used peptone as the sole nitrogen source, but not inorganic nitrogen compounds such as $\mathrm{NH}_{4} \mathrm{Cl},\left(\mathrm{NH}_{4}\right)_{2} \mathrm{SO}_{4}$, $\left(\mathrm{NH}_{4}\right)_{2} \mathrm{HPO}_{4}$ or $\mathrm{KNO}_{3}$. Very weak growth was observed on yeast extract, peptone, tryptone or amino acids as the sole energy and carbon source. Both strains grew at $20-42{ }^{\circ} \mathrm{C}$ and $\mathrm{pH} 6 \cdot 0-9 \cdot 5$, with optimum growth at $37-39^{\circ} \mathrm{C}$ and approximately $\mathrm{pH} 7 \cdot 5$. The strains could grow in the presence of $0-4 \%(\mathrm{w} / \mathrm{v}) \mathrm{NaCl}$. The mean generation time of the two strains was $8 \mathrm{~h}$ when grown in PYG at $37^{\circ} \mathrm{C}$.

The two strains exhibited almost identical physiological and biochemical profiles determined with conventional methods as well as with the API $50 \mathrm{CH}$ system. Both isolates hydrolysed aesculin and starch, but not gelatin. Milk was not curdled. Indole was not produced. Nitrate was not reduced. The strains produced acid from a few sugars such as glucose, arabinose, fructose, maltose and xylose (details in the species description below). The differences between the two isolates were that strain $\mathrm{ZLJ} 115^{\mathrm{T}}$ produced acid from ribose but not lactose, while strain L4-2 was the reverse. The end products of glucose fermentation by strains ZLJ115 ${ }^{\mathrm{T}}$ and L4-2 was acetate, ethanol, $\mathrm{H}_{2}$ and $\mathrm{CO}_{2}$; additional trace products including propionic acid, isobutyric acid and isovaleric acid were also observed from PY liquid. When co-cultured with a methanogen, Methanobacterium formicicum DSM $1535^{\mathrm{NT}}$, the end products of strain ZLJ115 ${ }^{\mathrm{T}}$ from glucose were shifted to acetate, $\mathrm{CH}_{4}$ and $\mathrm{CO}_{2}$, and no ethanol or hydrogen were produced at all (data not shown). Hydrogen production by the new isolates was at a maximum at $\mathrm{pH} 8.8$ and $39^{\circ} \mathrm{C}$, and $1 \cdot 4 \mathrm{~mol} \mathrm{H}_{2}$ was detected from fermentation of $1 \mathrm{molglucose}$. Sulfur $(150 \mathrm{mM})$ and sulfate $(20 \mathrm{mM})$ were not reduced. $\mathrm{H}_{2} \mathrm{~S}$ and $\mathrm{NH}_{3}$ were produced from PYG liquid.

The similarity of the complete $16 \mathrm{~S}$ rRNA gene sequences between strains $\mathrm{ZLJ} 115^{\mathrm{T}}$ and L4-2 was $98 \cdot 9 \%$ and their DNA G+C contents were 53.9 and $54.3 \mathrm{~mol} \%$, respectively. The two strains exhibited about $98 \%$ DNA-DNA relatedness; however, they gave slightly different cellular fatty acid profiles (Supplementary Table S1 available in IJSEM Online). The above results indicated single species status for the two isolates.

To ascertain the phylogenetic position of the isolates, complete 16S rRNA gene sequences (1495 bp) were compared with the most similar sequences retrieved from GenBank. On the basis of a consensus 1362 bp 16S rRNA gene sequence, a phylogenetic tree was constructed, rooted with Caloranaerobacter azorensis $\mathrm{MV} 1087^{\mathrm{T}}$ and Clostridium acidurici ATCC $7906^{\mathrm{T}}$ (Fig. 1). Phylogenetic analysis showed that the strains were affiliated to the phylum of low- $\mathrm{G}+\mathrm{C}$-content 


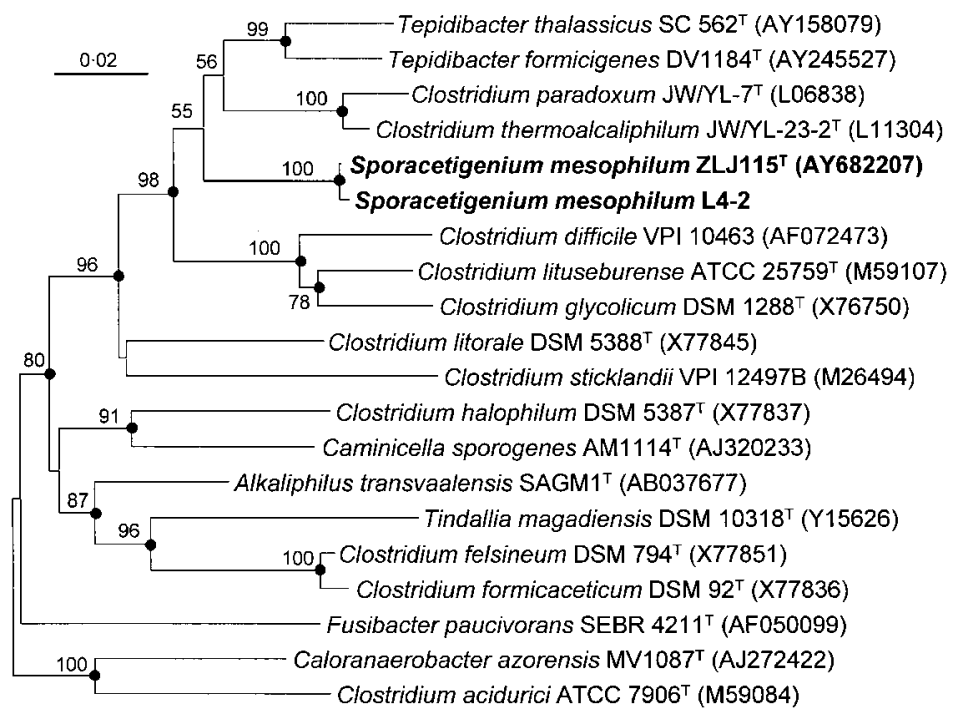

Fig. 1. Phylogenetic dendrogram showing the position of Sporacetigenium mesophilum ZLJ $115^{\top}$ and related species based on $16 \mathrm{~S}$ rRNA gene sequences. The tree was constructed using the neighbour-joining method and was rooted with Caloranaerobacter azorensis and Clostridium acidurici. Solid circles indicated that the corresponding nodes (groups) were also recovered in the maximum-likelihood and maximum-parsimony methods. Numbers at nodes represented percentage levels of bootstrap support based on a neighbour-joining analysis of 1000 resampled datasets. GenBank accession numbers are given in parentheses. Bar, $2 \%$ sequence divergence.

Gram-positive bacteria, and belonged to cluster XI of the genus Clostridium and related genera (Collins et al., 1994). Strain ZLJ115 ${ }^{\mathrm{T}}$ showed the highest $16 \mathrm{~S}$ rRNA gene sequence similarity to Clostridium thermoalcaliphilum (93.8\%) and Tepidibacter formicigenes $(93.7 \%)$, and $98 \%$ bootstrap support confirmed that the new isolates were clustered with C. thermoalcaliphilum, Clostridium paradoxum, T. formicigenes and Tepidibacter thalassicus. The similarities between strain $\mathrm{ZLJ} 115^{\mathrm{T}}$ and other related species in Clostridium cluster XI were all lower than $92.0 \%$ and the similarity between strain $\mathrm{ZLJ} 115^{\mathrm{T}}$ and the type species of the genus Clostridium (Clostridium butyricum, type strain ATCC $19398^{\mathrm{T}}$ ) was only $81 \cdot 8 \%$. The great sequence divergence indicated that the novel strains could represent a new genus in this cluster.

Phenotypic features of strains $\mathrm{ZLJ} 115^{\mathrm{T}}$ and L4-2 also distinguished them from related bacteria (Table 1). Firstly, the phylogenetically closest related species $C$. thermoalcaliphilum, T. formicigenes, T. thalassicus and C. paradoxum grow moderately thermophilically, at temperatures up to 55-60 ${ }^{\circ} \mathrm{C}$, while strains $\mathrm{ZLJ} 115^{\mathrm{T}}$ and $\mathrm{L} 4-2$ are mesophilic, growing at temperatures below $45^{\circ} \mathrm{C}$. Secondly, the DNA $\mathrm{G}+\mathrm{C}$ contents of the new isolates $(53 \cdot 9-54 \cdot 3 \mathrm{~mol} \%)$ are far higher than those of the related species (24-32 mol\%), proving that they belonged to a different genus. Furthermore, the PYG fermentation products of the new isolates included ethanol, propionic acid, isobutyric acid and isovaleric acid, while C. paradoxum and C. thermoalcaliphilum did not produce ethanol from glucose and $T$. formicigenes and $T$. thalassicus did not produce propionic acid, isobutyric acid or isovaleric acid. In addition, different profiles of fermentable sugars among the species were detected (Table 1); the new isolates fermented xylose, arabinose and ribose while the four related species did not.

Cell-wall hydrolysates of strains ZLJ115 ${ }^{\mathrm{T}}$ and L4-2 were rich in meso-DAP, similar to C. paradoxum but different from
C. thermoalcaliphilum, the cell wall of which is of the A4 $\beta$ (L-Orn-D-Asp) type. The predominant cellular fatty acids of strains $\mathrm{ZLJ} 115^{\mathrm{T}}$ and $\mathrm{L} 4-2$ were $\mathrm{C}_{14: 0}(16 \cdot 5$ and $7 \cdot 1 \%$, respectively), $\mathrm{C}_{16: 1} \omega 7 c(14 \cdot 1$ and $9 \cdot 4 \%)$ and $\mathrm{C}_{16: 0}(14 \cdot 0$ and $17 \cdot 0 \%)$, together with $3-\mathrm{OH} \mathrm{C}_{16: 0}(13 \cdot 6 \%)$ and $\mathrm{C}_{17: 1}$ iso $\mathrm{I}(8 \cdot 4 \%)$ in strain $\mathrm{ZLJ}_{11} 5^{\mathrm{T}}$ and $\mathrm{C}_{18: 1} \omega 9 c(32 \cdot 8 \%)$ and $\mathrm{C}_{18: 1} \omega 7 c(8 \cdot 4 \%)$ in strain L4-2. This differs from $C$. paradoxum $\left(60 \%\right.$ iso- $\mathrm{C}_{15: 0}$ at $\left.\mathrm{pH} 7 \cdot 5\right)$ and $C$. thermoalcaliphilum (iso- $\mathrm{C}_{15: 0}$, anteiso- $\mathrm{C}_{15: 0}$, iso- $\mathrm{C}_{13: 0}, \mathrm{C}_{16: 0}$, iso- $\mathrm{C}_{17: 0}, \mathrm{C}_{14: 0}$ and $\left.\mathrm{C}_{18: 0}\right)$.

The strains had the characteristics of Clostridium species (anaerobic, spores formed), while they were phylogenetically more closely related to other genera than to the type species of the genus Clostridium (C. butyricum). On the basis of the distant phylogenetic relationship with related taxa, unique chemotaxonomic characteristics, divergent DNA $\mathrm{G}+\mathrm{C}$ contents and distinct physiological and biochemical traits, it is evident that isolates ZLJ115 ${ }^{\mathrm{T}}$ and $\mathrm{L} 4-2$ represent a distinct genus within the cluster XI subgroup; therefore the name Sporacetigenium mesophilum gen. nov., sp. nov. is proposed.

\section{Description of Sporacetigenium gen. nov.}

Sporacetigenium [Spo.ra.ce.ti.ge'ni.um. Gr. n. spora seed; L. n. acetum vinegar; Gr. v. gennao to produce; N.L. neut. n. Sporacetigenium spored vinegar (acetate) producer].

Gram-positive, motile, spore-forming rods. Obligately anaerobic. No microaerophilic or aerobic growth occurs. The peptidoglycan of the cell wall contains meso-DAP. Strains are mesophilic (temperature range $\geqslant 20$ to $\leqslant 42{ }^{\circ} \mathrm{C}$ ) and grow in neutral to alkaline $\mathrm{pH}$. Chemo-organotrophy. Oxidase and catalase are not produced. Peptone may serve as nitrogen source. A few mono- and disaccharides are fermented. Starch and aesculin are hydrolysed, whereas gelatin is not. The major fermentation products from glucose include acetate, ethanol, hydrogen and carbon dioxide. 
Table 1. Characteristics that differentiate strains $Z \mathrm{~L} J 115^{\top}$ and $L 4-2$ from their phylogenetic relatives

Strains: 1, strain ZLJ115 ${ }^{\mathrm{T}}$; 2, strain L4-2; 3, C. paradoxum DSM $7308^{\mathrm{T}}$ (data from Li et al., 1993); 4, C. thermoalcaliphilum DSM 7309 ${ }^{\mathrm{T}}$ (Li et al., 1994); 5, T. thalassicus DSM 15285 (Slobodkin et al., 2003); 6, T. formicigenes DV1184 ${ }^{\mathrm{T}}$ (Urios et al., 2004). +, Positive; -, negative; $\mathrm{V}$, variable; $\mathrm{NR}$, not reported; $+\mathrm{W}$, weakly positive.

\begin{tabular}{|c|c|c|c|c|c|c|}
\hline Characteristic & 1 & 2 & 3 & 4 & 5 & 6 \\
\hline DNA G $+C$ content $(\mathrm{mol} \%)$ & $53 \cdot 9$ & $54 \cdot 3$ & 30 & 32 & 24 & 29 \\
\hline Products from $\mathrm{PYG}^{*}$ & A2ivibp & A2ivibp & Aivsb & Aivlsm & $\mathrm{A} 2$ & $\mathrm{~A} 2 \mathrm{~F}$ \\
\hline \multicolumn{7}{|l|}{ Temperature for growth $\left({ }^{\circ} \mathrm{C}\right)$ : } \\
\hline Range & $20-42$ & $20-42$ & $30-63$ & $27-57 \cdot 5$ & $33-60$ & $35-55$ \\
\hline Optimum & 37 & 37 & 56 & $48-51$ & 50 & 45 \\
\hline \multicolumn{7}{|l|}{$\mathrm{pH}$ for growth: } \\
\hline Range & $6 \cdot 0-9 \cdot 5$ & $6 \cdot 0-9 \cdot 5$ & $7 \cdot 3-11 \cdot 0$ & $7 \cdot 0-11 \cdot 0$ & $4 \cdot 8-8 \cdot 5$ & $5 \cdot 0-8 \cdot 0$ \\
\hline Optimum & $7 \cdot 5$ & $7 \cdot 5$ & $9 \cdot 8-10 \cdot 3$ & $9 \cdot 5-10 \cdot 0$ & $6 \cdot 5-6 \cdot 8$ & $6 \cdot 0$ \\
\hline Spore formation & + & + & + & - & + & + \\
\hline \multicolumn{7}{|l|}{ Acid produced from: } \\
\hline Xylose & + & + & - & - & - & - \\
\hline Arabinose & + & + & - & NR & - & - \\
\hline Ribose & + & - & - & - & NR & - \\
\hline Galactose & $+\mathrm{w}$ & $+\mathrm{w}$ & - & - & NR & - \\
\hline Rhamnose & $+\mathrm{w}$ & $+\mathrm{w}$ & - & - & NR & - \\
\hline Cellobiose & $+\mathrm{w}$ & $+\mathrm{W}$ & $\mathrm{V}$ & + & - & - \\
\hline Fructose & + & + & + & + & - & + \\
\hline Lactose & - & + & $\mathrm{V}$ & - & NR & - \\
\hline Cell-wall type & meso-DAP & meso-DAP & meso-DAP & L-Orn-D-Asp & NR & NR \\
\hline
\end{tabular}

${ }^{*}$ a, Acetic acid; b, butyric acid; f, formic acid; ib, isobutyric acid; 1 , lactic acid; $\mathrm{m}$, malic acid; $\mathrm{p}$, propionic acid; s, succinic acid; iv, isovaleric acid; 2, ethanol. Capitals indicate major products.

Sulfate is not reduced. The $\mathrm{G}+\mathrm{C}$ contents of the genomic DNA of the known strains are $53 \cdot 9-54 \cdot 3 \mathrm{~mol} \%$. Only one species, Sporacetigenium mesophilum, is described so far, and it is designated the type species.

\section{Description of Sporacetigenium mesophilum sp. nov.}

Sporacetigenium mesophilum (Gr. neut. n. meson the middle; N.L. adj. philus from Gr. adj. philos loving; N.L. neut. adj. mesophilum friendly to the middle, mesophilic, referring to its preference for moderate temperatures).

Morphology and general characters are as described for the genus. Cells are $0 \cdot 9-1 \cdot 0 \times 3 \cdot 6-7 \cdot 3 \mu \mathrm{m}$ in size. Optimal growth occurs at $37^{\circ} \mathrm{C}$. The $\mathrm{pH}$ range for growth is $5 \cdot 0-9 \cdot 5$ with an optimum at $\mathrm{pH} 6 \cdot 5-7 \cdot 0$. Acid is produced from a few mono- and disaccharides such as D-glucose, D-fructose, L-arabinose, D-xylose and D-maltose. D-Galactose, Dmannose, cellobiose, sucrose, rhamnose, trehalose, melibiose, melezitose and raffinose are fermented weakly. Acid is not produced from sorbose, starch, inulin, glycogen, salicin, amygdalin, glycerol, adonitol, dulcitol, erythritol, inositol, mannitol or sorbitol. Fermentation of D-lactose and ribose is variable. The following compounds are not utilized: methanol, ethanol, 1-propanol, citrate, fumarate, malate, succinate, malonic acid, hippurate, sodium gluconate, butanedioic acid, $\beta$-hydroxybutyric acid, phenylacetic acid, cellulose and xylan. Milk is not curdled. Urease, lecithinase and lipase are not produced. Methyl red test is positive while Voges-Proskauer test is negative. Nitrate is not reduced. $\mathrm{H}_{2} \mathrm{~S}$ and $\mathrm{NH}_{3}$ are produced from PYG. The predominant cellular fatty acids are $\mathrm{C}_{14: 0}(7 \cdot 1-16 \cdot 5 \%)$, $\mathrm{C}_{16: 1} \omega 7 c(9 \cdot 4-14 \cdot 1 \%)$ and $\mathrm{C}_{16: 0}(14 \cdot 0-17 \cdot 0 \%)$, together with 3-OH $\mathrm{C}_{16: 0}(13 \cdot 6 \%)$ and $\mathrm{C}_{17: 1}$ iso I $(8 \cdot 4 \%)$ detected in the type strain.

The type strain is strain $\mathrm{ZLJ} 115^{\mathrm{T}}\left(=\mathrm{DSM} 16796^{\mathrm{T}}=\mathrm{AS}\right.$ $\left.1.5019^{\mathrm{T}}\right)$, isolated from sludge of an anaerobic digester treating municipal solid waste and sewage.

\section{Acknowledgements}

This study was supported by the National Basic Research Program of China (2004CB719602) and the innovation program (field frontier) from Chinese Academy of Sciences and the '863' Program (2004AA227100).

\section{References}

Alain, K., Pignet, P., Zbinden, M. \& 8 other authors (2002). Caminicella sporogenes gen. nov., sp. nov., a novel thermophilic spore-forming bacterium isolated from an East-Pacific Rise hydrothermal vent. Int J Syst Evol Microbiol 52, 1621-1628. 
Cato, E. P., George, W. L. \& Finegold, S. M. (1986). Genus Clostridium Prazmowski 1880, 23 ${ }^{\mathrm{AL}}$. In Bergey's Manual of Systematic Bacteriology, vol. 2, pp. 1141-1200. Edited by P. H. A. Sneath, N. S. Mair, M. E. Sharpe \& J. G. Holt. Baltimore: Williams \& Wilkins.

Chen, S. \& Dong, X. (2004). Acetanaerobacterium elongatum gen. nov., sp. nov., from paper mill wastewater. Int J Syst Evol Microbiol 54, 2257-2262.

Collins, M. D., Lawson, P. A., Willems, A., Cordoba, J. J., FernandezGarayzabal, J., Garcia, P., Cai, J., Hippe, H. \& Farrow, J. A. E. (1994). The phylogeny of the genus Clostridium: proposal of five new genera and eleven new species combinations. Int J Syst Bacteriol 44, 812-826.

De Ley, J., Cattoir, H. \& Reynaerts, A. (1970). The quantitative measurement of DNA hybridization from renaturation rates. Eur J Biochem 12, 133-142.

Felsenstein, J. (1985). Confidence limits on phylogenies: an approach using the bootstrap. Evolution 39, 783-791.

Felsenstein, J. (1993). PHYLIP - Phylogenetic Inference Package, version $3.5 \mathrm{c}$. Distributed by the author. Department of Genome Sciences, University of Washington, Seattle, USA.

Fendrich, C., Hippe, H. \& Gottschalk, G. (1990). Clostridium halophilium sp. nov. and C. litorale sp. nov., an obligate halophilic and a marine species degrading betaine in the Stickland reaction. Arch Microbiol 154, 127-132.

Holdeman, L. V., Cato, E. P. \& Moore, W. E. C. (1977). Anaerobe Laboratory Manual, 4th edn. Blacksburg, VA: Virginia Polytechnic Institute and State University.

Hungate, R. E. (1969). A roll-tube method for cultivation of strict anaerobes. Methods Microbiol 3B, 117-132.

Kumar, S., Tamura, K., Jakobsen, I.-B. \& Nei, M. (2001). MEGA2: molecular evolutionary genetics analysis software. Bioinformatics 17, 1244-1245.

Lechevalier, M. P. \& Lechevalier, H. A. (1980). The chemotaxonomy of actinomycetes. In Actinomycete Taxonomy, Special Publication 6, pp. 227-291. Arlington, VA: Society for Industrial Microbiology.
Li, Y., Mandelco, L. \& Wiegel, J. (1993). Isolation and characterization of a moderately thermophilic anaerobic alkaliphile, Clostridium paradoxum sp. nov. Int J Syst Bacteriol 43, 450-460.

Li, Y., Engle, M., Weiss, N., Mandelco, L. \& Wiegel, J. (1994). Clostridium thermoalcaliphilum sp. nov., an anaerobic and thermotolerant facultative alkaliphile. Int J Syst Bacteriol 44, 111-118.

Marmur, J. (1961). A procedure for the isolation of deoxyribonucleic acid from microorganisms. J Mol Biol 3, 208-218.

Marmur, J. \& Doty, P. (1962). Determination of the base composition of deoxyribonucleic acid from its thermal denaturation temperature. J Mol Biol 5, 109-118.

Miller, L. T. (1982). Single derivatization method for routine analysis of bacterial whole-cell fatty acid methyl esters, including hydroxy acids. J Clin Microbiol 16, 584-586.

Nandi, R. \& Sengupta, S. (1998). Microbial production of hydrogen: an overview. Crit Rev Microbiol 24, 61-84.

Sasser, M. (1990). Identification of bacteria by gas chromatography of cellular fatty acids. Technical Note 101. Newark, DE: MIDI, Inc.

Slobodkin, A. L., Tourova, T. P., Kostrikina, N. A., Chernyh, N. A., Bonch-Osmolovskaya, E. A., Jeanthon, C. \& Jones, B. E. (2003). Tepidibacter thalassicus gen. nov., sp. nov., a novel moderately thermophilic, anaerobic, fermentative bacterium from a deep-sea hydrothermal vent. Int J Syst Evol Microbiol 53, 1131-1134.

Smibert, R. M. \& Krieg, N. R. (1994). Phenotypic characterization. In Methods for General and Molecular Bacteriology, pp. 607-654. Edited by P. Gerhardt, R. G. E. Murray, W. A. Woods \& N. R. Krieg. Washington, DC: American Society for Microbiology.

Thompson, J. D., Gibson, T. J., Plewniak, F., Jeanmougin, F. \& Higgins, D. G. (1997). The CLUSTAL_X windows interface: flexible strategies for multiple sequence alignment aided by quality analysis tools. Nucleic Acids Res 25, 4876-4882.

Urios, L., Cueff, V., Pignet, P. \& Barbier, G. (2004). Tepidibacter formicigenes sp. nov., a novel spore-forming bacterium isolated from a Mid-Atlantic Ridge hydrothermal vent. Int J Syst Evol Microbiol 54, 439-443. 